\title{
JUKMAS
}

Jurnal Untuk Masyarakat Sehat (JUKMAS)

e-ISSN : 2715-7687

Vol. 4, No. 1 April 2020

P-ISSN : 2715-8748

\section{Hubungan Obesitas Dengan Hipertensi Pada Pra Lansia di Puskesmas Sukamulya Tahun 2019}

\author{
Robo Marliana Rahayu, Aurelia Alget Berthelin, Azizah Lapepo, Marselia Wulansari \\ Utam, Jumiati Lelu Sanga, Ike Wulandari, Anak Agung Sagung Ratu P.S, Yeny \\ Sulistyowati \\ Universitas Respati Indonesia \\ Email: yeny.sulistyowati@urindo.ac.id
}

\begin{abstract}
ABSTRAK
Kemajuan ilmu pengetahuan dan teknologi serta perbaikan sosial ekonomi berdampak pada peningkatan derajat kesehatan masyarakat dan usia harapan hidup, sehingga jumlah populasi Lansia juga meningkat serta pergeseran pola penyakit. Penelitian ini ditujukan untuk menganalisa hubungan indeks massa tubuh dengan hipertensi pada pra lansia usia 45 - 55 tahun di Puskesmas Sukamulya, Tanggerang, Banten. Penelitian ini menggunakan data sekunder pada sejumlah 517 populasi pra lansia. Hasil perhitungan sampel didapatkan 225 orang, dengan teknik sampling probability sampling, metode systematic random sampling. Hasil penelitian ini menunjukkan bahwa ada hubungan yang signifikan antara Indeks Massa Tubuh dengan Hipertensi Pada Pra Lansia Usia 45-55 Tahun di Puskesmas Sukamulya. Temuan dalam penelitian ini berimplikasi pada pentingnya memperhatikan faktor IMT serta hipertensi, sehingga di harapkan agar saat Lansia melewati hari-hari dalam hidupnya dengan kualitas hidup yang semakin baik.
\end{abstract}

Kata kunci: obesitas, hipertensi, pra lansia.

\begin{abstract}
Advances in science and technology as well as socioeconomic improvements have an impact on improving the degree of public health and life expectancy, so that the number of the elderly population also increases and shifts in disease patterns. This study aimed to analyze the relationship of body mass index with hypertension in pre elderly aged 45 - 55 years at the Sukamulya Health Center, Tangerang, Banten. This study uses secondary data from a total of 517 pre-elderly populations. The sample calculation results obtained 225 people, with probability sampling technique, systematic random sampling method. The results of this study indicate that there is a significant relationship between Body Mass Index and Hypertension in Pre-Elderly Aged 45-55 Years at Sukamulya Health Center. The findings in this study have implications for the importance of paying attention to $\mathrm{BMI}$ and hypertension factors, so that it is expected that when the Elderly passes the days of his life with a better quality of life.

Keywords: obesity, hypertension, pre elderly.
\end{abstract}

\section{PENDAHULUAN}

Penduduk di 11 negara anggota

World Health Organization (WHO)

kawasan Asia Tenggara yang berusia di atas 60 tahun berjumlah 142 juta orang dan diperkirakan akan terus meningkat hingga 3 kali lipat di tahun $2050^{(1)}$. 
Populasi Lansia di Indonesia sendiri pada tahun 2020 sekitar 80.000 .000 Lansia $^{(2,3)}$. Seiring degan bertambahnya usia harapan hidup bangsa Indonesia masalah beralih dari penyakit infeksi ke penyakit degenertif. Hipertensi merupakan salah satu penyakit degeneratif yang saat ini makin bertambah jumlahnya di Indonesia. Hipertensi atau darah tinggi sampai saat ini masih jadi penyakit pembunuh nomor satu di Indonesia, belakangan penyakit tersebut tak hanya menyerang usia produktif tetapi pada pra lansia karena faktor degeneratif. Tekanan darah tinggi atau hipertensi berarti tekanan tinggi di dalam arteri. Arteri adalah pembuluh yang mengangkut darah dari jantung yang memompa ke seluruh jaringan dan organ-organ tubuh. Tekanan darah tinggi bukan berarti tegangan emosi yang berlebihan, meskipun tegangan emosi dan stress dapat meningkatkan tekanan darah untuk sementara waktu ${ }^{(4)}$.

Tekanan darah tinggi atau hipertensi secara umum didefinisikan sebagai tekanan sistolik lebih dari 140 $\mathrm{mmHg}$ dan tekanan diastolik lebih dari 90 mmHg. Penyakit hipertensi merupakan penyakit kelainan jantung yang ditandai oleh meningkatnya tekanan darah dalam tubuh. Seseorang yang terjangkit penyakit ini biasanya berpotensi mengalami penyakit-penyakit lain,seperti stroke dan penyakit jantung. Tidak ada tanda-tanda pasti yang bisa dijadikan pegangan untuk mengetahui kemunculannya ${ }^{(5)}$. Berdasarkan beberapa teori, yang dimaksud dengan hipertensi adalah peningkatan tekanan darah secara terus menerus sehingga melebihi batas normal. Tekanan darah normal adalah 120/80 mmHg. Telah dikemukakan di atas bahwa penyebab hipertensi yang telah diketahui adalah hipertensi sekunder, sedangkan penyebab hipertensi esensial belum diketahui secara pasti. Adapun penyebab dari hipertensi sekunder antara lain kelainan pembuluh darah ginjal, gangguan kelenjar tiroid (hipertiroid), dan penyakit kelenjar adrenal (hiperaldosterorisme). Seseorang yang menderita hipertensi akan memiliki penderitaan yang lebih berat lagi jika semakin banyak faktor risiko yang menyertai. Hampir $90 \%$ penderita hipertensi tidak diketahui penyebabnya dengan pasti. Para ahli membagi dua kelompok faktor risiko pemicu timbulnya hipertensi, yaitu faktor yang tidak dapat dikontrol dan faktor yang dapat dikontrol.

$$
\text { Salah satu indikator dalam }
$$
menentukan faktor resiko dari hipertensi yaitu berat badan yang dalam 
kategorikan dalam kategori normal, kurang, overweight dan obesitas. Sedangkan salah satu alat ukur utuk mengetahui kategorik tersebut yaitu dengan menghitung IMT. IMT merupakan salah satu indikator kadar relatif lemak tubuh seseorang yang digunakan untuk menentukan status berat badan apakah seseorang memiliki badan kurus, ideal, atau terlalu gemuk dan membantu menilai status berat badan seseorang terhadap resiko masalah kesehatan akibat kekurangan atau kelebihan berat badan ${ }^{(6)}$.

Faktor faktor yang dapat
mempengaruhi indeks masa tubuh
adalah pola makan yang buruk, kurangnya aktfitas fisik, gaya hidup, umur, pekerjaan, informasi tentang kesehatan, sedangkan faktor yang mempengaruhi terjadi hipertensi meliputi faktor resiko yang tidak dapat dikendalikan (Mayor) dan faktor yang dapat dikendalikan (Minor). Faktor resiko yang tidak dapat dikendalikan (mayor) seperti keturunan, jenis kelamin, ras, umur. Sedangkan faktor resiko yang dapat dikendalikan (Minor) yaitu, olahraga, banyakna konsumsi garam, alkohol, faktor stress, kelebihan berat badan, dan kebiasaan makan makanan yang siap saji. Menurut Supariasa, (2012) (7) Indeks massa tubuh diterjemahkan menjadi yang merupakan alat yang sederhana untuk memantau setatus gizi khususnya yang berkaitan dengan kekurangan dan kelebihan berat badan. IMT merupakan salah satu indikator kadar relatif lemak tubuh seseorang yang digunakan untuk menentukan setatus berat badan apakah seseorang memiliki badan kurus, ideal, atau terlalu gemuk dan membantu menilai setatus berat badan seseorang terhadap resiko masaah kesehatan akibat kekurangan atau kelebihan berat badan (8). IMT adalah rumus matematis yang berkaitan dengan lemak tubuh orang dewasa, dan dinyatakan sebagai berat badan (dalam kilogram) dibagi dengan kuadrat tinggi badan (dalam ukuran meter) : IMT = BB/TB. Faktor-faktor yang mempengaruhi IMT adalah: Perilaku Makan, diantaranya adalah pola makan dan kebiasaan tidak melakuakan olah raga. Sosial ekonomi dan genetik. Faktor keturunan juga sangat berpengaruh terhadap keadaan fisik seseorang ${ }^{(6) .}$

Sejalan dengan latarbelakang permasalahan yang ada, maka peneliti tertarik untuk meneliti hubungan indeks masa tubuh dengan kejadian hipertensi pada pra lansia yang berusia $45-55$ tahun di Puskesmas Sukamulya. 
METODE

Jenis penelitian ini

menggunakan pendekatan cross

sectional, yaitu penelitian dari beberapa populasi yang beragam diamati pada waktu yang sama, dan peneliti observasi atau pengukuran variabel pada satu waktu tertentu. Penelitian dilaksanakan pada bulan Februari 2020 dengan pengambilan data sekunder pada bulan Oktober-Desember 2019. Variabel independen pada penelitian ini adalah Indeks Massa Tubuh (IMT), variabel dependen dalam penelitian ini adalah tekanan darah pada penderita hipertensi.

Populasi adalah objek penelitian atau objek yang akan diteliti ${ }^{(9)}$. Pada penelitian ini populasinya adalah semua pra lansia usia 45-55 tahun di Puskesmas Sukamulya, Tangerang sejumlah 517 orang. Sampel merupakan bagian populasi yang akan diteliti atau sebagian jumlah dari kareakteristik yang dimiliki oleh populasi. Sampel dalam penelitian ini adalah sebagian pra lansia usia 45-55 tahun di Puskesmas Sukamulya, Tangerang. Dalam penelitisn ini untuk menentukan sampel, peneliti menggunakan rumus Slovin. Dengan tingkat kesalahan $5 \%$ atau 0,05 adalah sebagai berikut sejumlah 225 orang. Teknik sampling yang digunakan dalam penelitian ini adalah probability sampling dengan metode systematic random sampling, yaitu pengambilan sampel dengan cara acak tanpa memperhatikan strata yang ada dalam anggota populasi tetapi pengambilannya diberikan nomor urut $^{(10)}$.

\section{HASIL}

\section{Gambaran Lokasi Penelitian}

Kecamatan Sukamulya terletak di Kabupaten Tangerang. Sebelah Utara berbatasan dengan kecamatan Kronjo, Sebelah Timur berbatasan dengan kecamatan Kemiri dan kecamatan Rajeg, Sebelah Selatan berbatasan dengan kecamatan Balaraja dankecamatan Jayanti, Sebelah Barat berbatasan dengan kecamatan Kresek. Kecamatan Sukamulya memiliki 8 desa wilayah kerja diantaranyaDesa Sukamulya, Desa Kaliasin, Desa Merak, Desa Parahu, Desa Bunar, Desa Buniayu, Desa Benda dan Desa Kubang. Jumlah penduduk di Kecamatan Sukamulya sebanyak 66.821 jiwa yang terdiri dari 34.004 penduduk laki-laki dan 32.817 penduduk perempuan. 


\section{Karakteristik Responden berdasarkan jenis kelamin Di Puskesmas Sukamulya}

Karakteristik responden berdasarkan jenis kelamin digambarkan pada Tabel 1.

Tabel 1. Jenis Kelamin Responden di Puskesmas Sukamulya

\begin{tabular}{cccc}
\hline No & Jenis kelamin & Jumlah & Persen (100\%) \\
\hline 1. & Laki-laki & 45 & 20 \\
2. & Perempuan & 180 & 80 \\
\hline & Total & 255 & 100
\end{tabular}

Sumber : Data Sekunder 2019

\begin{abstract}
Berdasarkan Tabel 1, sebagian
besar responden berjenis kelamin
\end{abstract}

perempuan sebanyak 180 responden (80\%).

\begin{abstract}
Karakteristik responden berdasarkan umur di Puskesmas Sukamulya

Karakteristik responden berdasarkan umur di Puskesmas Sukamulya digambarkan pada Tabel 2.
\end{abstract}

Tabel 2. Umur Responden di Puskesmas Sukamulya

\begin{tabular}{cccc}
\hline No & Umur & Jumlah & Persen (100\%) \\
\hline 1. & $45-48$ tahun & 82 & 36,4 \\
2. & $49-52$ tahun & 86 & 38,2 \\
3. & $53-55$ tahun & 57 & 25,3 \\
\hline & Total & 225 & 100
\end{tabular}

Sumber : Data Sekunder 2019

Berdasarkan Tabel 2, sebagian besar responden berusia 49-52 tahun sebanyak 86 responden $(38,2 \%)$ dan sebagian kecil responden berusia 53-55 tahun sebanyak 57 responden $(25,3 \%)$.
Indeks Massa tubuh pra lansia usia 4555 tahun di Puskesmas Sukamulya Indeks Massa tubuh pra lansia usia 45-55 tahun di Puskesmas Sukamulya digambarkan pada Tabel 3. 
Jurnal Untuk Masyarakat Sehat (JUKMAS)

Tabel 3. Indeks Massa Tubuh Pra Lansia Usia 45-55 tahun di Puskesmas Sukamulya

\begin{tabular}{cccc}
\hline No & IMT & Jumlah & Persen (100\%) \\
\hline 1. & Kurus & 17 & 7,6 \\
2. & Normal & 89 & 39,6 \\
3. & Gemuk & 46 & 20,4 \\
4. & Obesitas & 73 & 32,4 \\
\hline & Total & 225 & 100 \\
\hline
\end{tabular}

Sumber : Data Sekunder 2019

Berdasarkan Tabel 3, hampir seluruh indeks Massa Tubuh pada responden normal sebanyak 89 responden $(39,6 \%)$ dan sebagian kecil adalah kurus sebanyak 17 responden $(7,6 \%)$.
Hipertensi pada pra lansia 45-55 tahun di Puskesmas Sukamulya

Hipertensi pada pra lansia 45-55 tahun di Puskesmas Sukamulya dihgambarkan pada Tabel 4.

Tabel 4. Hipertensi pada Pra Lansia Usia 45-55 tahun di Puskesmas Sukamulya

\begin{tabular}{cccc}
\hline No & Hipertensi & Jumlah & Persen (100\%) \\
\hline 1. & Normal & 91 & 40,4 \\
2. & Hipertensi ringan & 54 & 24,0 \\
3. & Hipertensi sedang & 45 & 20 \\
4. & Hipertensi berat & 35 & 15,6 \\
\hline & Total & 225 & 100
\end{tabular}

Sumber : Data Sekunder 2019

Berdasarkan Tabel 4, didapat bahwa sebagian besar responden tidak mengalami hipertensi yaitu sebanyak 91 responden $(40,4 \%)$, dan sebagian kecil mengalami hipertensi berat yaitu sebanyak 35 orang $(15,6 \%)$.
Hubungan Indeks Massa tubuh Dengan Hipertensi Pada Pra Lansia Usia 45-55 Tahun di Puskesmas Sukamulya tahun 2019.

Hubungan Indeks Massa tubuh Dengan Hipertensi Pada Pra Lansia Usia 45-55 Tahun di Puskesmas Sukamulya tahun 2019 ditampilkan pada Tabel 5. 
Jurnal Untuk Masyarakat Sehat (JUKMAS)

Tabel 5. Hubungan Indeks Massa tubuh dengan Hipertensi pada Pra Lansia

Usia 45-55 tahun di Puskesmas Sukamulya

\begin{tabular}{cccccc}
\hline IMT & \multicolumn{4}{c}{ Hipertensi } & Total \\
\cline { 2 - 5 } & Normal & $\begin{array}{c}\text { Hipertensi } \\
\text { ringan }\end{array}$ & $\begin{array}{c}\text { Hipertensi } \\
\text { sedang }\end{array}$ & $\begin{array}{c}\text { Hipertensi } \\
\text { berat }\end{array}$ & \\
\hline Kurus & 11 & 3 & 1 & 2 & 17 \\
Normal & 44 & 19 & 17 & 9 & 89 \\
Gemuk & 14 & 16 & 10 & 6 & 46 \\
Obesitas & 22 & 16 & 17 & 18 & 73 \\
\hline Total & 91 & 54 & 45 & 35 & 225 \\
\hline
\end{tabular}

Sumber : Data Sekunder 2019

Tabel 5 menunjukkan bahwa sebagian besar responden yang mengalami hipertensi berat masuk dalam kategori obesitas sebanyak 18 dari 35 responden $(24,7 \%)$ dan sebagian kecil responden yang mengalami hipertensi berat masuk dalam kategori badan kurus sebanyak 2 responden dari 35 responden yang mengalami hipertensi berat (11,8\%).

Dari hasil analisa data dengan menggunakan uji chi-square diketahui nilai signifikan 0,031 lebih rendah dari 0,05 artinya $\mathrm{H}_{0}$ ditolak dan $\mathrm{H}_{1}$ diterima. Hal ini berarti ada hubungan antara variabel Indeks Massa Tubuh Dengan Hipertensi Pada Pra Lansia Usia 45-55 Tahun dimana semakin Tinggi Indeks Massa Tubuh maka akan menyebabkan Hipertensi. Hasil penelitian ini menunjukkan bahwa ada hubungan yang signifikan antara Indeks Massa Tubuh dengan Hipertensi Pada Pra Lansia Usia 45-55 Tahun di Puskesmas Sukamulya.

\section{PEMBAHASAN}

Indeks Massa Tubuh Pada Pra Lansia Usia 45-55 Tahun di Puskesmas Sukamulya

Hasil penelitian sebagian besar Indeks Massa Tubuh adalah normal sebanyak 89 responden $(39,6 \%)$ dan sebagian kecil adalah kurus sebanyak 17 responden (7,6\%). Didapatkan juga informasi bahwa sebagian besar yang mengalami hipertensi berat adalah responden yang mengalami obesitas yaitu sebanyak 18 responden $(24,7 \%)$ dan sebagian kecil yang mengalami hipertensi berat adalah responden dengan badan kurus sebanyak 2 responden $(11,8 \%)$ dari total 35 
responden yang mengalami hipertensi berat. Indeks massa tubuh (IMT) merupakan alat yang sederhana untuk memantau status gizi orang dewasa khususnya yang berkaitan dengan kekurangan dan kelebihan berat badan. Penggunaan IMT hanya berlaku untuk orang dewasa berumur diatas 18 tahun. IMT tidak dapat diterapkan pada bayi, anak, remaja, ibu hamil, olahragawan ${ }^{(7)}$.

Seiring dengan bertambahnya usia, kebutuhan zat gizi karbohidrat dan lemak umumnya lebih rendah karena adanya penurunan metabolime basal. Proses metabolisme yang menurun pada usia lanjut akan beresiko mengakibatkan kegemukan karena terjadi penurunan aktifitas fisik, maka kalori yang berlebih akan diubah menjadi lemak sehingga mengakibatkan kegemukan. Proses menua menyebabkan proporsi lemak dan otot dalam tubuh berubah. Semakin tua dan melemah sehingga menyebabkan kegemukan. Puncak kenaikan berat badan pada wanita terjadi pada usia 5565 tahun dan pria pada usia 34-54 tahun (11).

\section{Hipertensi Pada Pra Lansia Usia 45-55}

\section{Tahun di Puskesmas Sukamulya}

Hasil penelitian sebagian besar dari responden mengalami tekanan darah normal yaitu sebanyak 91 responden $(40,4 \%)$, Hipertensi Ringan sebanyak 54 responden (24,0\%),

Hipertensi Sedang sebanyak 45 responden $(20,0 \%)$ dan Hipertensi Berat sebanyak 35 responden (15,6\%). Hipertensi sering diartikan sebagai suatu keadaan dimana tekanan darah sistolik lebih dari $120 \mathrm{mmHg}$ dan tekanan diastolik lebih dari $80 \mathrm{mmHg}{ }^{(12)}$. Faktor hipertensi yang tidak dapat diubah adalah umur, jenis kelamin, dan genetik. Faktor resiko hipertensi yang dapat diubah meliputi obesitas/kegemukan, psikososial dan stress, merokok dan olahraga yang kurang, konsumsi alkohol berlebih, konsumsi garam berlebih, hyperlipidemia/hiperkolestrolemia.

Sedangkan penyebab sekunder hipertensi antara lain penyakit ginjal, gangguan endokrin, dan penggunaan obat-obatan seperti kontrasepsi pil.

Sebagian besar responden berusia 49-52 tahun yaitu sebanyak 86 responden (38,2\%). Menurut peneliti semakin bertambahnya usia mengakibatkan perubahan fisiologis dalam tubuh dan berakibat pada penebalan pada dinding arteri dan semakin lama akan menyempit mengakibatkan aliran darah terganggu dan kerja jantung menjadi lebih berat. Seiring dengan bertambahnya usia, hampir setiap orang mengalami kenaikan tekanan darah, tekanan sistolik terus 
meningkat sampai usia 80 tahun dan tekanan distolik terus meningkat sampai usia 55-60 tahun, kemudian berkurang secara perlahan atau bahkan menurun secara drastis.

\section{Hubungan Indeks Massa Tubuh Dengan}

Hipertensi Pada Pra Lansia Usia 45-55

\section{Tahun di Puskesmas Sukamulya.}

Hasil penelitian ini diketahui bahwa sebagian besar responden yang mengalami hipertensi berat masuk dalam kategori obesitas sebanyak 18 dari 35 responden $(24,7 \%)$ dan sebagian kecil responden yang mengalami hipertensi berat masuk dalam kategori badan kurus sebanyak 2 responden dari 35 responden yang mengalami hipertensi berat $(11,8 \%)$. Kegemukan erat hubungannya dengan hipertensi. Pada saat masa menopause perempuan memiliki risiko hipertensi yang sama dengan pria dikarenakan perubahan hormonalnya dimana faktor protektor tidak dihasilkan lagi juga ditunjang dengan kenaikan berat badan ${ }^{(8)}$.

Menurut peneliti bahwa pada usia diatas 45 tahun perempuan memasuki masa menopause dimana fungsi organorgan dalam tubuh mengalami penurunan. Sehingga metabolisme dalam tubuh juga menurun mengakibatkan lemak semakin menumpuk didalam pembuluh darah sehingga kerja jantung semakin berat berhubungan dengan tekanan darah naik. Jadi hal ini ada hubungan indeks massa tubuh dengan hipertensi pada pra lansia 45-55 tahun.

Risiko terkena hipertensi dengan berat badan lebih, berpeluang 2,3 kali dibandingkan dengan berat badan normal dan kurus. Responden dengan berat badan lebih akan terjadi penumpukan jaringan lemak, yang dapat menyebabkan peningkatan resistensi pembuluh darah dalam meningkatkan kerja jantung untuk dapat memompakan darah ke seluruh tubuh.

Hasil penelitian tersebut diperkuat oleh hasil perbedaan melalui nilai uji chi square yang berarti $\mathrm{H}_{0}$ ditolak dan $\mathrm{H}_{1}$ diterima yaitu ada hubungan antara Indeks Massa Tubuh Dengan Hipertensi Pada Pra Lansia Usia 45-55 Tahun di Puskesmas Sukamulya. Dengan adanya kondisi tersebut, diperlukan diet tinggi serat bagi pra lansia. Terjadinya hal ini erat hubungannya dengan meningkatnya densitas energi dari diet sehari-hari. Peningkatan kadar serat dalam diet dapat menurunkan penyerapan energi. Serat juga mampu memberikan perasaan kenyang lebih lama sehingga keinginan untuk makan makanan lain akan menjadi berkurang. Kebutuhan serat bagi tubuh tiap hari sekitar 25-30 mg/hari. Sumber 
serat yang baik adalah sayuran seperti bayam, sawi, kangkung, kentabg, kubis, dan buah seperti alpukat, pisang, melon, jeruk serta kacang-kacangan seperti kacang-kacangan seperti kacang buncis, kedelai, kacang merah.

\section{SIMPULAN}

1. Indeks massa tubuh pada responden pra lansia usia 45-55 tahun di Puskesmas Sukamulya bervariasi yaitu normal 89 responden $(39,6 \%)$, obesitas 73 responden $(32,4 \%)$, gemuk 46 responden $(20,4 \%)$ dan kurus 17 responden (7,6\%). Dari data ini obesitas tetap menjadi permasalahan meskipun berada pada urutan kedua dari data indeks massa tubuh pada responden di Puskesmas Sukamulya.

2. Tekanan darah pada responden pra lansia usia 45-55 tahun di Puskesmas Sukamulya masih dalam batas normal yaitu 91 responden $(40,4 \%)$ namun jumlah responden yang mengalami hipertensi berat masih cukup banyak yaitu 35 responden (15,6\%).

3. Ada hubungan indeks massa tubuh dengan hipertensi pada pra lansia usia 45-55 tahun di Puskesmas Sukamulya. Kategori obesitas dengan hipertensi berat sebanyak 18 dari 35 responden (73\%).

\section{DAFTAR PUSTAKA}

1. UNDESA (United Nation for Departement of Economic and Social Affair). World Population Prospect 2019. New York, USA; 2019.

2. Kementerian Badan Penelitian dan Pengembangan Kesehatan. Hasil utama Riskesdas 2018 Kesehatan. 2018;20-1.

3. Kementrian Kesehatan RI (Ministry of Health Republic Indonesia). Situasi lanjut usia 2016 (Elderly Situation of 2016). 2016;1.

4. Dalimartha. 2008. Care Your Self Hipertensi. Jakarta: Penebar Plus.

5. Frederick. 2012. Bahaya Hipertensi. Bandung Rosdakarya.

6. Arisman. 2010. Gizi Dalam Daur Kehidupan. Jakarta: EGC

7. Supariasa. 2012. Status Gizi. Bandung. AIFABETA.

8. Miraharini. 2016. Obesitas. Jakarta Rineka Cipta.

9. Arikunto. 2010. Prosedur Penelitian. Jakarta:EGC.

10. Nursalam. 2009. Konsep Dan Penerapan Metodologi Penelitian IImu Keperawatan. Jakarta: Salemba Medika.

11. Proverati dan Maesaroh. 2009. Perilaku Hidup Sehat Dengan Peningkatan Status Gizi. Surabaya :Air Langga.

\section{Susyanti. 2012. Pencegahan} Hipertensi. Jakarta: ISBN. 